\title{
ANALISIS PENGARUH FAKTOR FUNDAMENTAL DAN PASAR TERHADAP HARGA SAHAM PADA PERUSAHAAN MANUFAKTUR YANG TERDAFTAR DI BURSA EFEK INDONESIA
}

\author{
Oleh: \\ Anastasia F. Karo-Karo \\ Dr. Donalson Silalahi
}

\begin{abstract}
This study aimed to analyze the influence Earning Per Share, Return on Equity, Book Value, Growth Company and market factors, namely Capitalization Rate on stock price on manufacturing companies listed in Indonesia Stock Exchange. The object of this research is manufacturing companies listed in Indonesia Stock Exchange 2010-2012 period who actively publish the financial statements in the period of observation. In this study, the data collected is of secondary data is data obtained indirectly from the object of research. Therefore, in this study the data capture technique using the documentation techniques. The procedure of sample selection is purposive sampling and analysis model used is the Multiple regression to test the hypothesis that the t test and F test and also performed classical assumption. The results showed that the Earning Per Share, Return on Equity, Book Value positive and significant effect on stock prices and capitalization rates and a significant negative effect on stock prices. Based on the test results indicate that simultaneous Earning Per Share, Return on Equity, Book Value, Growth companies and capitalization rates affect stock prices. Variations independent variable Earning Per Share, Return on Equity, Book Value, Growth companies and capitalization rate is able to explain the variation in stock prices by $95.64 \%$.
\end{abstract}

Keywords: Fundamentals, Factors Market, Stock Price

\section{Latar Belakang}

\section{PENDAHULUAN}

Pasar modal memiliki peran penting bagi perekonomian suatu negara karena pasar modal menjalankan dua fungsi, yaitu pertama sebagai sarana pendanaan usaha atau sebagai sarana bagi perusahaan untuk mendapatkan dana dari masyarakat pemodal (investor). Dana yang diperoleh dari pasar modal dapat digunakan untuk pengembangan usaha, ekspansi, penambahan modal kerja, dan lain-lain, kedua pasar modal menjadi sarana bagi masyarakat untuk berinvestasi pada instrument keuangan seperti saham, obligasi, reksadana dan lain-lain. Dengan demikian masyarakat dapat menempatkan dana yang dimilikinya sesuai dengan karakteristik keuntungan dan risiko masing-masing instrument.

Siklus pasar modal tidak lepas dari hukum ekonomi, yaitu permintaan dan penawaran, artinya semakin banyak investor yang menanamkan uangnya di saham maka harga pasar secara logis naik. Sebaliknya jika investor saham berkurang maka harga pasar secara logis akan turun. Ada sejumlah faktor yang mempengaruhi masyarakat atau investor untuk membeli atau menjual sahamnya, yaitu faktor-faktor ekonomi, sosial dan politik. Dua variabel utama dalam faktor ekonomi adalah tingkat suku bunga dan nilai kurs.

Bagi investor, pasar modal merupakan wahana untuk menginvestasikan dananya di pasar modal tidak hanya bertujuan dalam jangka pendek tetapi juga bertujuan untuk memperoleh pendapatan dalam jangka panjang. Pendapatan yang diinginkan oleh para pemegang saham adalah pendapatan dividen (dividen yield) dan capital gain, semakin tinggi harga pasar menunjukkan bahwa saham tersebut juga semakin diminati oleh investor karena 
semakin tinggi harga saham akan menghasilkan capital gain yang semakin besar pula. Capital gain merupakan selisih antara harga pasar periode sekarang dengan harga periode sebelumnya.

Investor perlu melakukan penilaian terlebih dahulu terhadap saham-saham yang akan dipilihnya dalam mengambil keputusan berinvestasi, selanjutnya menentukan apakah saham tersebut akan memberikan tingkat return yang sesuai dengan tingkat yang diharapkan. Dalam penilaian saham dikenal adanya tiga jenis nilai yaitu: nilai buku, nilai pasar, dan nilai intrinsik saham. Nilai buku merupakan nilai yang dihitung berdasarkan pembukuan perusahaan penerbit saham (emiten). Nilai pasar adalah nilai saham di pasar yang ditunjukkan oleh harga saham tersebut di pasar. Sedangkan nilai intrinsik atau dikenal sebagai nilai teoritis adalah nilai saham sebenarnya atau seharusnya terjadi. Investor akan membandingkan nilai intrinsik dengan nilai pasar saham bersangkutan pada saat menjual atau membeli saham. Jika nilai pasar suatu saham lebih tinggi dari nilai intrinsiknya maka saham tersebut tergolong mahal (over value). Dalam hal seperti ini, sebaiknya investor mengambil keputusan untuk menjual saham tersebut. Sebaliknya jika nilai pasar saham berada dibawah nilai intrinsiknya, berarti saham tersebut tergolong murah (under value), sehingga dalam situasi seperti ini investor sebaiknya membeli saham tersebut. Dua analisis yang banyak digunakan untuk menentukan nilai sebenarnya dari saham adalah analisis sekuritas fundamental (fundamental security analysis) dan analisis teknis (technical analysis). Laporan keuangan perusahaan memegang peranan penting. Dengan mengevaluasi laporan keuangan, analis akan mengetahui perkembangan dan kondisi keuangan perusahaan. Investor merasa perlu menganalisis keadaan keuangan perusahaan. Karena kondisi dan keuangan perusahaan akan mempengaruhi kemampuannya untuk membagikan dividen. Analisis keuangan dapat dilakuakan dengan menghitung rasio-rasio keuangan perusahaan baik yang berkaitan dengan likuiditas, rentabilitas, efisiensi, maupun struktur modalnya.

Penelitian-penelitian tentang hubungan pertumbuhan perusahaan dengan harga saham masih sedikit mendapat perhatian dari peneliti-peneliti terdahulu, walaupun ada dasar teori untuk menghipotesiskan bahwa pertumbuhan perusahaan mempunyai hubungan dengan harga saham perusahaan. Untuk perusahaan yang tidak tumbuh, yaitu perusahaan yang mempunyai peluang tumbuh yang terbatas, diprediksi mempunyai hubungan yang negatif dengan harga saham. Sedangkan untuk perusahaan yang tumbuh, yaitu perusahaan yang memiliki peluang tumbuh yang tinggi diramalkan memiliki hubungan positif dengan harga saham.

Harga merupakan salah satu penentu keberhasilan suatu perusahaan karena harga menentukan seberapa besar keuntungan yang akan diperoleh perusahaan dari penjualan produknya baik berupa barang maupun jasa. Menetapkan harga terlalu tinggi akan menyebabkan penjualan akan menurun, namun jika harga terlalu rendah akan mengurangi keuntungan yang dapat diperoleh perusahaan.

Dalam menentukan penetapan harga, perusahaan tidak hanya memperhatikan harga namun perlunya perhatian khusus mengenai faktor-faktor diluar harga yang mempengaruhi jumlah permintaan, situasi pasar secara global, perilaku konsumen, siklus kehidupan produk dan lain-lain, sehingga strategi penetapan harga ini dapat terarah, efektif, dan sesuai dengan tujuan perusahaan atas produk atau jasa yang dihasilkannya (Budianas, 2013).

Harga saham merupakan harga jual beli yang sedang berlaku di pasar efek yang ditentukan oleh kekuatan pasar dalam arti tergantung pada kekuatan permintaan dan penawaran. Harga pasar saham juga menunjukkan nilai dari perusahaan itu sendiri. Semakin tinggi nilai dari harga pasar saham suatu perusahaan, maka investor akan tertarik untuk menjual sahamnya. Bursa saham merupakan salah satu indikator perekonomian suatu negara 
maka diperlukan suatu perhitungan tentang transaksi yang terjadi dalam bursa sepanjang periode tertentu. Perhitungan ini akan digunakan sebagai tolak ukur kondisi perekonomian suatu negara. Untuk di Indonesia perhitungan tersebut adalah perhitungan Indeks Harga Saham Gabungan (IHSG).

Kapitalisasi pasar sebenarnya merupakan nilai dari saham perusahaan yang beredar di pasar. Harap dipahami bahwa nilai perusahaan berbeda dengan nilai aset perusahaan, sehingga kapitalisasi pasar sebuah perusahaan tidak menggambarkan nilai aset perusahaan. Kapitalisasi pasar sangat mungkin nilainya lebih besar atau lebih kecil dari nilai aset perusahaan. Bagi perusahaan publik, kapitalisasi pasar ini penting sekali karena ia juga mencerminkan nilai total perusahaan. Nilai kapitalisasi pasar ditentukan oleh dua hal, yakni jumlah saham beredar dan harga di pasar. Dari sini dapat disimpulkan bahwa nilai kapitalisasi pasar perusahaan dapat dan selalu berubah dari waktu ke waktu, baik naik ataupun turun. Jika harga saham naik, berarti nilai perusahaan itu naik dan sebaliknya jika harga turun berarti nilai perusahaan itu turun.

Perusahaan manufaktur secara umum adalah perusahaan yang kegiatannya mengolah bahan mentah (bahan baku) menjadi barang jadi yang siap untuk digunakan oleh masyarakat. Kata manufaktur berasal dari bahasa Latin manus factus yang berarti dibuat dengan tangan. Kata manufakture muncul pertama kali tahun 1576, dan kata manufacturing muncul tahun 1683. Manufaktur, dalam arti yang paling luas adalah proses mengubah bahan baku menjadi produk. Proses ini meliputi (1) perancangan produk, (2) pemilihan material, dan (3) tahaptahap proses dimana produk tersebut dibuat.

Setianingsih (2006) melakukan penelitian terhadap harga saham dilakukan mengenai faktor fundamental dan resiko pasar terhadap harga saham. Hasil penelitian menunjukkan bahwa faktor fundamental dan faktor risiko secara simultan mempengaruhi harga saham. Secara parsial dividen kas mempengaruhi harga saham sedangkan variabel yang lain tiak mempunyai pengaruh. Nainggolan (2008) melakukan penelitian tentang "Pengauh Faktor Fundamental Terhadap Harga Saham Pada Perusahaan Manufaktur yang Terdaftar di Bursa Efek Indonesia". Hasil penelitian menunjukkan bahwa faktor fundamental yang terdiri dari ROA, DER, ROE, BVS secara simultan tidak berpengaruh secara signifikan terhadap harga saham. Secara parsial menunjukkan bahwa hanya BVS yang berpengaruh terhadap harga saham. Fitryana (2011) melakukan penelitian terhadap harga saham mengenai pengaruh faktor fundamental dan faktor pasar terhadap harga saham. Hasil penelitian pada perusahaan sektor Real Estate dan Property ini menunjukkan bahwa variabel pasar yang digunakan yaitu selisih tingkat kapitalisasi dengan tingkat bunga bebas resiko (CAP-RF) dan variabel fundamental yaitu ROE, BV dan RR secara simultan mempunyai pengaruh yang signifikan terhadap harga saham. Secara parsial menunjukkan bahwa ROE, BV dan selisih tingkat kapitalisasi dengan tingkat bunga bebas resiko (CAP-RF) memiliki pengaruh yang positif terhadap harga saham, sedangkan RR memiliki pengaruh yang negatif terhadap harga saham.

Dari hasil penelitian terdahulu mendorong peneliti untuk melakukan penelitian lebih lanjut tentang hubungan atau pengaruh EPS, ROE, BV, dan Tingkat Kapitalisasi terhadap harga saham dengan menambahkan variabel bebas yaitu Pertumbuhan Perusahaan untuk membedakan penelitian dengan penelitian sebelumnya.

\section{Pengertian Harga Saham}

\section{TINJAUAN PUSTAKA}

Harga saham adalah harga dari suatu saham yang ditentukan pada saat pasar saham sedang berlangsung dengan berdasarkan kepada permintaan dan penawaran pada saham yang 
dimaksud. Harga saham yang berlaku di pasar modal biasanya ditentukan oleh para pelaku pasar yang sedang melangsungkan perdagangan sahamnya. Dengan harga saham yang ditentukan otomatis perdagangan saham di bursa efek akan berjalan. Sementara saham sendiri adalah suatu kepemilikan asset seperti instrument dari kegiatan finansial suatu perusahaan yang biasa disebut juga dengan efek. Harga saham dari suatu perusahaan tentu saja berbedabeda tergantung bagaimana nilai jual perusahaan tersebut di bursa saham.

Faktor-faktor yang mempengaruhi harga saham menurut Brigham (2001) adalah : (a) laba per Lembar Saham, (b) tingkat Suku Bunga, (c) jumlah Kas Dividen yang diberikan, (d) jumlah Laba yang diperoleh Perusahaan, (e) Tingkat Risiko dan Pengembalian. Menurut Alwi (2003) ada beberapa faktor yang mempengaruhi pergerakan harga saham, antara lain: (a) faktor Internal (Lingkungan mikro), (2) Faktor eksternal (Lingkungan makro)

Dari ke dua pendapat para ahli tersebut maka dapat disimpulkan bahwa faktor internal yaitu keadaan situasi laporan keuangan suatu perusahaan dapat mempengaruhi harga saham perusahaan tersebut.

\section{Pengaruh Earning per Share terhadap Harga Saham}

EPS merupakan perbandingan antara jumlah earning after tax (EAT) dengan jumlah saham yang beredar. EPS merupakan salah satu rasio keuangan yang sering digunakan oleh investor untuk menganalisa kemampuan perusahaan menghasilkan laba berdasarkan saham yang dimiliki. EPS merupakan komponen penting yang harus diperhatikan dalam analisa perusahaan, karena informasi EPS suatu perusahaan menunjukkan besarnya laba bersih perusahaan yang siap dibagikan kepada semua pemegang saham dengan kata lain menggambarkan prospek earning perusahaan di masa mendatang. Besarnya EPS dapat diketahui dari informasi laporan keuangan perusahaan (Tandelilin, 2001).

EPS ini akan sangat membantu investor karena informasi EPS ini bisa menggambarkan prospek earning suatu perusahaan dimasa yang akan datang karena EPS menunjukkan laba bersih perusahaan yang siap dibagikan kepada semua pemegang saham perusahaan, maka semakin besar EPS akan menarik investor untuk melakukan investasi diperusahaan tersebut. Oleh karena itu, hal tersebut akan mengakibatkan permintaan akan saham meningkat dan harga saham akan meningkat, dengan demikian EPS berpengaruh positif terhadap harga saham.

Keterkaitan Earning Per Share (EPS) terhadap harga saham dapat dilihat sebagai berikut

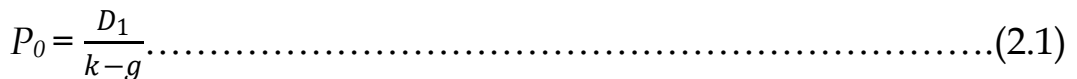

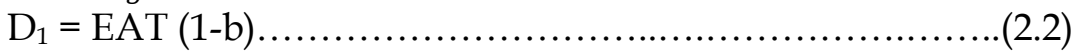

Dividen $\left(\mathrm{D}_{1}\right)$ dapat diperoleh dari laba bersih setelah pajak (Earning After Tax) dikalikan dengan persentasi laba yang dibagikan kepada para investor, karena b adalah laba yang ditahan oleh perusahaan. Kemudian substitusikan persamaan (2.2) ke persamaan (2.1), sehingga menjadi:

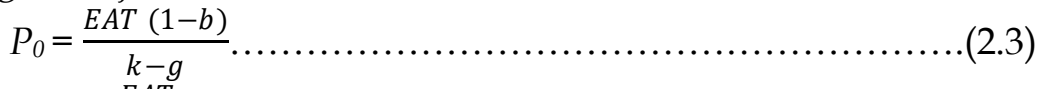

$$
\begin{aligned}
& E P S=\frac{E A T}{N} \text {.. } \\
& P_{0}=\frac{(E P S \times N)(1-b)}{k-g}
\end{aligned}
$$

Dimana: $\mathrm{P}_{0}=$ Harga Saham, $\mathrm{D}_{1}=$ Dividen, $\mathrm{k}=$ Tingkat Kapitalisasi, $\mathrm{g}=$ Tingkat Pertumbuhan, EAT = Laba bersih setelah pajak, $\mathrm{b}=$ Laba yang ditahan, $\mathrm{N} \quad=$ Laba yang dibagikan kepada para investor 
Dari persamaan di atas diperoleh bahwa tingkat Earning Per Share (EPS) memiliki pengaruh yang positif terhadap harga saham. Semakin tinggi EPS maka harga saham semakin tinggi, sebaliknya jika EPS rendah maka harga saham akan semakin rendah.

\section{Pengaruh Return on Equity terhadap Harga Saham}

ROE juga merupakan ukuran kinerja perusahaan ditinjau dari segi profitabilitasnya. Kemampuan menghasilkan laba bersih setelah pajak dari modal yang dimiliki oleh perusahaan menunjukkan kinerja yang semakin baik. ROE yang semakin meningkat, maka investor semakin tertarik untuk menanamkan dananya ke dalam perusahaan, sehingga harga saham cenderung meningkat. Dengan demikian ROE berhubungan positif dengan harga saham.

Keterkaitan Return On Equity (ROE) terhadap harga saham dapat dilihat sebagai berikut

Tingkat pertumbuhan (G) merupakan hasil perkalian rasio probabilitas yaitu Return On Equity (ROE) dikali dengan rasio laba ditahan (b). sehingga persamaannya menjadi :

$g=R O E x b$.

Kemudian substitusikan persamaan (2.6) ke persamaan (2.5), sehingga menjadi :

$$
P_{0}=\frac{(E P S \times N)(1-b)}{k-(R O E \times b)}
$$

Dari persamaan di atas diperoleh bahwa tingkat probabilitas yang diukur dengan ROE memiliki pengaruh yang positif terhadap harga saham. Hal ini terjadi jika ROE naik, berarti manajemen mampu mengelola ekuitas secara optimal untuk menghasilkan laba bersih. Kondisi ini akan mendorong investor untuk membeli saham, sehingga harga saham naik.

\section{Pengaruh Book Value terhadap Harga Saham}

Book Value (nilai/harga buku per lembar saham) pada dasarnya mewakili jumlah asset/ekuitas yang dimiliki perusahaan tersebut. Secara normal, book value suatu perusahaan akan terus naik seiring dengan naiknya kinerja perusahaan demikian pula sebaliknya, sehingga book value ini penting untuk mengetahui kapasitas dari harga per lembar suatu saham serta dalam penentuan wajar atau tidaknya harga saham di pasar. Dengan demikian secara tidak langsung dapat disimpulkan bahwa book value berpengaruh positif terhadap harga saham (Tryfino, 2009).

Keterkaitan Book Value (BV) terhadap harga saham dapat dilihat sebagai berikut : Menurut Husnan (2001), EPS dapat dihitung dari perkalian antara ROE dengan BV, sehingga persamaannya menjadi:

$$
E P S=R O E x B V
$$

Kemudian substitusikan persamaan (2.8) ke persamaan (2.5), sehingga menjadi:

$$
P_{0}=\frac{(R O E \times B V \times N)(1-b)}{k-g} \text {....... }
$$

Dari persamaan di atas diperoleh bahwa tingkat Book Value (BV) memiliki pengaruh yang positif terhadap harga saham. Semakin tinggi BV maka harga saham semakin tinggi, sebaliknya jika BV semakin rendah maka harga saham akan semakin rendah.

\section{Pengaruh Pertumbuhan Perusahaan Terhadap Harga Saham.}

Pertumbuhan perusahaan sangat diharapkan oleh pihak internal maupun eksternal suatu perusahaan karena dapat memberikan suatu aspek yang positif bagi mereka. Dari sudut pandang investor, pertumbuhan suatu perusahaan merupakan tanda bahwa perusahaan memiliki aspek yang menguntungkan, dan mereka mengharapkan rate of return (tingkat pengembalian) dari investasi mereka memberikan hasil yang lebih baik. 
Harga saham yang dipengaruhi oleh kebijakan struktur modal tergantung pada peluang tumbuh dari perusahaan tersebut. Untuk perusahaan yang tidak tumbuh (memiliki peluang tumbuh yang terbatas) harga saham akan merespon secara negatif jika perusahaan tersebut memiliki lebih sedikit equity di dalam struktur modalnya. Sedangkan untuk perusahaan yang tumbuh (perusahaan yang memiliki peluang tumbuh yang tinggi) harga saham akan merespon secara positif jika perusahaan tersebut memiliki lebih banyak equity di dalam struktur modalnya.

Dari persamaan 2.6 dapat diketahui Tingkat pertumbuhan (g) merupakan hasil perkalian Return On Equity (ROE) dengan rasio laba ditahan (b). Dan dari persamaan 2.7 dapat diketahui hubungan antara pertumbuhan perusahaan dengan harga saham:

$$
P_{0}=\frac{(E P S \times N)(1-b)}{k-(\text { ROExb })}
$$

Dari persamaan di atas diperoleh bahwa pertumbuhan perusahaan memiliki pengaruh yang positif terhadap harga saham. Hal ini terjadi jika pertumbuhan perusahaan naik, berarti manajemen mampu mengelola ekuitas secara optimal untuk menghasilkan laba bersih. Kondisi ini akan mendorong investor untuk membeli saham, sehingga harga saham naik.

\section{Pengaruh Tingkat Kapitalisasi terhadap Harga Saham.}

Kapitalisasi pasar menunjukkan nilai efek yang tercatat di bursa saham. Atau secara definisi diartikan sebagai total nilai surat berharga yang diterbitkan oleh berbagai perusahaan di dalam satu pasar. Penurunan harga saham akan mengakibatkan menurunnya kapitalisasi pasar bursa efek. Sebaliknya, penambahan jumlah saham dan kenaikan harga saham, akan memicu kenaikan kapitalisasi pasar.

Banyak cara yang dapat dipergunakan dalam menentukan tingkat kapitalisasi, menurut Hampton (1995), tingkat kapitalisasi dapat dihitung dengan rumus sebagai berikut:

$$
\text { Tingkat kapitalisasi }=\frac{\text { Earning Per Share }}{\text { harga per lembar saham }}
$$

\section{Over capitalization akan terjadi apabila :}

1. Earning tidak cukup besar untuk mendapatkan pengembalian dari jumlah modal yang di investasikan, atau dengan kata lain rata-rata tingkat pengembalian lebih kecil dari pada tingkat adil pengembalian.

2. Jumlah nilai surat-surat berharga yang ada di dalam peredaran lebih besar dari pada nilai riil dibandingkan dengan nilai assetnya.

Under capitalization terjadi apabila :

1. Rata-rata tingkat pengembalian dari perusahaan tersebut jauh lebih tinggi dibandingkan dengan tingkat pengembalian dari modal yang diinvestasikan dalam perusahaan yang sejenis lainya.

2. Jumlah nilai surat berharga yang tercantum dalam neraca jauh lebih kecil daripada nilai riil daripada assetnya.

Cara mengatasi over capitalization dapat diatasi dengan cara mengurangi jumlah nilai nominal modal saham atau mengurangi jumlah lembar saham yang beredar. Sedangkan cara mengatasi under capitalization dapat diatasi dengan cara mengadakan stock splits, yaitu pemecahan jumlah lembar saham menjadi jumlah lembar yang lebih banyak dengan pengurangan harga nominal per lembar secara proporsional dan stock devident, yaitu pembayaran deviden dalam bentuk saham dan bukan dalam bentuk kas.

Keterkaitan tingkat kapitalisasi terhadap harga saham dapat dilihat sebagai berikut: 


$$
P_{0}=\frac{(\mathrm{EPS} \times \mathrm{N})(1-\mathrm{b})}{\mathrm{k}-(\mathrm{ROE} \times \mathrm{b})}
$$

Dari persamaan di atas diperoleh bahwa tingkat kapitalisasi memiliki pengaruh yang negatif terhadap harga saham. Hal ini terjadi jika tingkat kapitalisasi naik, maka harga saham akan turun sebaliknya jika tingkat kapitalisasi turun maka harga saham naik.

\section{Ruang Lingkup Penelitian}

\section{METODE PENELITIAN}

Penelitian ini bertujuan untuk mengetahui pengaruh faktor-faktor fundamental yakni Earning per Share (EPS), Return on Equity (ROE), Book Value (BV), Pertumbuhan Perusahaan (G) dan variabel pasar yakni tingkat kapitalisasi $(K)$ terhadap harga saham perusahaan manufaktur yang terdaftar di Bursa Efek Indonesia pada tahun 2010 sampai dengan tahun 2012.

\section{Populasi dan Sampel}

Populasi penelitian adalah seluruh perusahaan manufaktur yang terdaftar di Bursa Efek Indonesia pada periode 2010 sampai dengan 2012 yang berjumlah 146 perusahaan. Teknik pengambilan sampel yang digunakan peneliti dalam penelitian ini adalah teknik Purposive Sampling dengan kriteria yang digunakan untuk pemilihan sampel adalah sebagai berikut:

1. Emiten yang tetap listing di Bursa Efek Indonesia selama periode 2010-2012 dan merupakan perusahaan manufaktur.

2. Perusahaan tersebut secara periodic mempublikasikan laporan keuangan tiap tahunnya dan memiliki data selama periode pengamatan.

3. Ekuitas perusahaan yang diteliti selama periode 2010-2012 tidak negatif.

Adapun perusahaan manufaktur yang menjadi sampel dalam penelitian ini sebanyak 49 perusahaan. Untuk memisahkan sampel penelitian berdasarkan perusahaan besar dan perusahaan kecil dilakukan dengan criteria:

Kriteria besar kecilnya suatu perusahaan menurut Undang-Undang Republik Indonesia No. 20 tahun 2008 pasal 6, yaitu dapat disimpulkan sebagai berikut :

a. Jika perusahaan memiliki penjualan bersih kurang dari atau sama dengan $\mathrm{Rp}$ 2.500.000.000,- (dua milyar lima ratus juta rupiah) dikatakan perusahaan menengah ke bawah (perusahaan kecil).

b. Jika perusahaan memiliki penjualan bersih lebih dari Rp 2.500.000.000,- (dua milyar lima ratus juta rupiah) dikatakan perusahaan menengah ke atas (perusahaan besar).

Pada penelitian ini, peneliti mengolah nilai rata-rata dari penjualan bersih untuk menetukan besar kecilnya perusahaan manufaktur di Bursa Efek Indonesia selama periode pengamatan yaitu tahun 2010-2012.

\section{Operasionalisasi Variabel}

Operasional variabel merupakan batasan pokok pembahasan yang akan diteliti dan diamati sesuai dengan perumusan masalah. Adapun variabel yang akan diteliti dalam penelitian ini adalah:

1. Variabel independent adalah Rasio keuangan dengan indikator;

a. Earning Per Share (EPS)

EPS merupakan ukuran yang digunakan untuk menunjukkan jumlah uang yang dihasilkan dari setiap lembar saham biasa. Rasio ini dapat dihitung sebagai berikut:

$$
E P S=\frac{E A T}{\text { Jumla } h \text { Saham Outstanding }}
$$

\section{b. Return on Equity (ROE)}


Mengukur tingkat keuntungan dari investasi yabg telah dilakukan oleh pemilik modal sendiri atau pemegang saham. Semakin tinggi ROE menunjukkan semakin efisien perusahaan dalam menggunakan modal sendiri untuk menghasilkan laba atau keuntungan bersih.

$$
R O E=\frac{E A T}{\text { Total Equity }}
$$

c. Book Value (BV)

BV merupakan rasio menggambarkan perbandingan total modal (equity) terhadap jumlah saham. BV digunakan untuk melihat harga suatu sekuritas apakah overpriced atau underprice.

$$
B V=\frac{\text { Total Equity }}{\text { Share }}
$$

d. Pertumbuhan Perusahaan (G)

Pertumbuhan perusahaan diefinisikan sebagai sebuah perusahaan dengan kemampuan manajemen dan kesempatan untuk melakukan investasi yang menghasilkan tingkat pengembalian lebih besar bagi perusahaan.

$$
\mathrm{g}=\frac{P t-P 0}{P 0}
$$

\section{e. Tingkat Kapitalisasi (K)}

Tingkat Kapitalisasi (K) adalah rasio yang digunakan untuk mengukur tingkat pengembalian yang dituntut oleh pasar terhadap perusahaan. Jika rasio harga laba meningkat, maka tingkat kapitalisasi (K) akan menurun. Pada penelitian ini, peneliti mengolah nilai ratarata dari tingkat kapitalisasi perusahaan manufaktur di Bursa Efek Indonesia selama periode pengamatan yaitu tahun 2010-2012 dengan menggunakan skala rasio.

Tingkat Kapitalisasi diukur dengan rumus Hampton(1995) :

$$
\text { Tingkat kapitalisasi }=\frac{\text { Earning Per Share }}{\text { harga per lembar saham biasa }}
$$

2. Variabel dependent

Yaitu variabel yang dipengaruhi oleh variabel dependent. Yang termasuk variabel dependent adalah harga saham. Harga Saham yaitu sejumlah uang yang dibayarkan atau diterima investor untuk mendapatkan atau melepaskan satu lembar saham. Indikator pengukurannya adalah closing price tanggal 31 Desember tahun 2010-2012. Pada penelitian ini, peneliti mengolah nilai rata-rata dari harga saham perusahaan manufaktur di Bursa Efek Indonesia selama periode pengamatan yaitu tahun 2010-2012 dengan menggunakan skala rasio.

\section{Teknik Pengumpulan Data}

Data diperoleh dari dokumentasi yaitu mengumpulkan data yang sudah dipublikasikan dari berbagai sumber seperti Indonesian Capital Market Directory (ICMD), situs resmi Bursa Efek Indonesia (BEI) www.idx.co.id.

\section{Teknik Analisis Data}

Teknik analisis data yang digunakan adalah regresi linear berganda dengan rumus:

$\log (Y)=\alpha+\beta 1 \log X 1+\beta 2 \log X 2+\beta_{3} \log X_{3}+\beta_{4} \log X_{4}+\beta_{5} \log X_{5}+\varepsilon$

$\log \left(Y_{k}\right)=\alpha+\beta_{1 k} \log X_{1 k}+\beta 2 k \log X 2 k+\beta 3 k \log X 3 k+\beta 4 k \log X 4 k+\beta_{5 k} \log X_{5 k}+\varepsilon_{k}$

$\log \left(Y_{b}\right)=a+\beta_{1 b} \log X_{1 b}+\beta_{2 b} \log X_{2 b}+\beta 3 b \log X 3 b+\beta 4 b \log X 4 b+\beta_{5 b} \log X_{5 b}+\varepsilon_{b}$

Dimana:

Y

$Y_{k}$

$Y_{b}$
: Harga Saham

: Harga saham perusahaan kecil

: Harga saham perusahaan besar 


$\begin{array}{ll}\mathrm{a} & : \text { Konstanta } \\ \beta_{1}, \beta_{2}, \beta_{3}, \beta_{4}, \beta_{5} & : \text { Koefisien Regresi } \\ \mathrm{X}_{1} & : \text { Return On Equity (ROE) } \\ \mathrm{X}_{2} & : \text { Book Value (BV) } \\ \mathrm{X}_{3} & : \text { Earning Per Share (EPS) } \\ \mathrm{X}_{4} & : \text { Pertumbuhan Perusahaan (G) } \\ \mathrm{X}_{5} & : \text { Tingkat kapitalisasi (K) } \\ \varepsilon & : \text { error term (variabel pengganggu) } \\ \text { Log } & : \text { Logaritma }\end{array}$

Pengujian Hipotesis secara Simultan (Uji F) dan Secara Parsial (Uji-t)

Pengujian Asumsi Klasik

1. Uji Normalitas

Metode yang dipakai dalam model ini adalah metode Jargue-Berra Test. Uji normalitas dari Jargue-Berra Test (JB) adalah asimptotis untuk sampel besar. Uji yang didasarkan pada residual OLS dengan rumus:

$J B=T\left[\frac{S^{2}}{6}+\frac{(K-3)^{2}}{24}\right]$

Dimana S dan K masing-masing adalah koefisien skewness dan koefisien kurtosis. Model regresi yang baik adalah yang memiliki distribusi data normal atau mendekati normal. Pedoman pengambilan keputusan yaitu:

a. $\quad$ Nilai signifikan atau probabilitas $<0,05$ (Distribusi tidak normal)

b. Nilai signifikan atau probabilitas $>0,05$ (Distribusi normal) (Manurung, 2010)

2. Uji Multikolinieritas

Uji multikolinieritas diukur oleh Variance Inflating Factor (VIF) yaitu:

$V I F=\frac{1}{1-R_{i j}^{2}}$

Dimana $R_{i j}$ adalah koefisien determinasi variabel regressor $X_{i}$ dan $X_{j}$. Jika VIF $>10$ maka terjadi multikolinieritas yang serius, sebaliknya jika $\mathrm{VIF}<10$ maka multikolinieritas tidak serius (Manurung, 2010).

\section{Uji Autokorelasi}

Untuk mendeteksi data ada tidaknya autokorelasi maka dilakukan uji Durbin-Watson Test atau $D W$-statistik yaitu:

$D W=\frac{\sum_{t=n}^{t=n}\left(\varepsilon_{t}-\varepsilon_{t-1}\right)^{2}}{\sum_{t=n}^{t=n}(\varepsilon)^{2}}$

Dengan ketentuan sebagai berikut:

a. $0.005 \leq D W \leq d_{L}$ dengan kesimpulan terjadi autokorelasi positif

b. $D_{L} \leq D W \leq d_{u}$ dengan kesimpulan invonclusive

c. $D_{u} \leq D W \leq 4.00-d_{u}$ dengan kesimpulan tidak terdapat autokorelasi

d. $4.00-d_{u} \leq D W \leq d_{L}$ dan $4.00-d_{u} \leq D W \leq 4.00$ dengan kesimpulan terjadi autokorelasi negative.

1. Uji Heteroskedastisitas

Untuk mendeteksi keberadaan heteroskedastisitas digunakan dengan metode white.

Kriteria pengujian adalah sebagai berikut:

1. Ho : diterima bila nilai Prob*R-square $>a=$ tidak ada heteroskedastisitas.

2. Ho : ditolak bila nilai Prob*R-square $<a=$ terdapat heteroskedastisitas. 
Dalam penelitian menggunakan Logaritma yang berfungsi untuk memperoleh data yang lebih halus dan juga penelitian ini menggunakan Program EViews 7.

Hasil Penelitian

\section{HASIL PENELITIAN DAN PEMBAHASAN}

Hasil analisis deskriptif dapat dilihat pada table 1 berikut:

Table 1.

Data Deskriptif Perusahaan Manufaktur yang Terdaftar di Bursa Efek Indonesia Periode 2010-2012

\begin{tabular}{|l|c|c|c|c|c|c|}
\hline & $\begin{array}{c}\mathbf{P} \\
(\mathbf{R p ~ 0 0 0 )}\end{array}$ & $\begin{array}{c}\text { EPS } \\
(\mathbf{R p ~ 0 0 0 )}\end{array}$ & $\begin{array}{c}\mathbf{R O E} \\
(\mathbf{\%})\end{array}$ & $\begin{array}{c}\mathbf{B V} \\
(\mathbf{R p ~ 0 0 0 )}\end{array}$ & $\begin{array}{c}\mathbf{G} \\
\mathbf{( \% )}\end{array}$ & $\begin{array}{c}\mathbf{K} \\
(\mathbf{\%})\end{array}$ \\
\hline Mean & 11,028 & 431 & 18.47 & 7,358 & 18.57 & 9.65 \\
\hline Maximum & 162,167 & 10,641 & 106.22 & 73,461 & 52.92 & 47 \\
\hline Minimum & 160 & 3 & 0.87 & 373 & 2.52 & 0.01 \\
\hline Std.Dev. & 29,780 & 1,512 & 15.33 & 14,172 & 10.57 & 8.35 \\
\hline Observation & 49 & 49 & 49 & 49 & 49 & 49 \\
\hline
\end{tabular}

Sumber: Lampiran 2 diolah menggunakan MS Excel.

Rata-rata Earning Per share (EPS) pada perusahaan manufaktur yang terdaftar di Bursa Efek Indonesia periode 2010-2012 yaitu sebesar Rp. 431, rata-rata Return On Equity (ROE) pada perusahaan manufaktur yang terdaftar di Bursa Efek Indonesia periode 2010-2012 yaitu sebesar 18,47 persen, rata-rata Book Value (BV) pada perusahaan manufaktur yang terdaftar di Bursa Efek Indonesia periode 2010-2012 yaitu sebesar Rp. 7.358, rata-rata Pertumbuhan Perusahaan (G) pada perusahaan manufaktur yang terdaftar di Bursa Efek Indonesia periode 2010-2012 yaitu sebesar 18,57 persen, rata-rata Tingkat kapitalisasi (K) pada perusahaan manufaktur yang terdaftar di Bursa Efek Indonesia periode 2010-2012 yaitu sebesar 9,65 persen.

\section{UJI REGRESSI LINEAR BERGANDA}

Adapun hasil estimasi pengaruh Earning Per Share (EPS), Return On Equity (ROE), Book Value (BV), Pertumbuhan Perusahaan (G) dan Tingkat Kapitalisasi (K) terhadap Harga Saham dapat dilihat pada table 4.2 berikut ini:

Tabel 2.

Regressi Linear Berganda pada Perusahaan Manufaktur yang terdaftar di Bursa Efek Indonesia Periode 2010-2012

Dependent Variable: LOGHARGASAHAM

Method: Least Squares

Date: 06/10/14 Time: 09:54

Sample: 159

Included observations: 49

\begin{tabular}{crrrr}
\hline \hline Variable & Coefficient & Std. Error & t-Statistic & Prob. \\
\hline \hline LOGEPS & 0.608645 & 0.075434 & 8.068593 & 0.0000 \\
LOGROE & 0.368401 & 0.100950 & 3.649338 & 0.0007 \\
LOGBV & 0.378354 & 0.071768 & 5.271882 & 0.0000 \\
LOGG & 0.182963 & 0.096288 & 1.900163 & 0.0641 \\
LOGK & -0.714897 & 0.067943 & -10.52208 & 0.0000
\end{tabular}




\begin{tabular}{|c|c|c|c|}
\hline $\mathrm{C}$ & 1.641715 & 0.636572 & 0.0134 \\
\hline R-squared & 0.956414 & Mean dependent var & 7,796331 \\
\hline Adjusted R-squared & 0.951346 & S.D. dependent var & 1,731710 \\
\hline F-statistic & 188.7111 & Durbin-Watson stat & 2.229717 \\
\hline Prob(F-statistic) & 0.000000 & & \\
\hline
\end{tabular}

Sumber: Lampiran 2 diolah menggunakan Eviews 7

\section{UJI ASUMSI KLASIK}

Setelah dilakukan pengujian asumsi klasik diperoleh hasilnya yaitu sebagai berikut: Nilai Jargue Berra sebesar 32,56007 $<X^{2}$ tabel sebesar 65,17 maka dapat disimpulkan bahwa residualnya berdistribusi secara normal, Dari hasil perhitungan VIF untuk masing-masing variabel terlihat bahwa $\mathrm{VIF}<10$, artinya tidak terjadi multikolinieritas pada masing-masing variabel pada perusahaan manufaktur yang terdaftar di Bursa Efek Indonesia selama periode pengamatan yaitu 2010-2012, Hasil output menunjukkan nilai Obs*R-Squared adalah sebesar 8,52 sedangkan nilai probabilitas (chi-square) adalah 0,13 (lebih besar daripada $\alpha=0,05$ ), dengan demikian dapat disimpulkan bahwa model empiris yang digunakan tidak mengandung masalah heteroskedastisitas, dari hasil output diatas di dapat nilai Durbin Watson yang dihasilkan dari model regresi adalah 2,198986. Sedangkan dari tabel Durbin Watson dengan signifikansi 0,05 dan jumlah sampel 49 serta jumlah variabel independen 5 diperoleh nilai dL sebesar 1,37007 dan dU sebesar 1,72095 dan karena dU (1,72095) $\leq$ DW $(2,198986) \leq 4,00-d U$ $(2,27095)$ maka dapat disimpulkan bahwa model diatas tidak terdapat autokorelasi.

\section{PENGUJIAN HIPOTESIS}

Berdasarkan hasil pengujian dengan metode regressi linear berganda pada table 4.1, maka dapat disimpulkan sebagai berikut: Laba perlembar saham, return on equity, Book Value (BV) mempunyai pengaruh positif dan signifikan terhadap Harga Saham pada perusahaanperusahaan maufaktur yang terdaftar di Bursa Efek Indonesia, sedangkan Pertumbuhan Perusahaan (G) mempunyai pengaruh dan positif dan tidak signifikan terhadap Harga Saham pada perusahaan-perusahaan maufaktur yang terdaftar di Bursa Efek Indonesia, tingkat Kapitalisasi (K) mempunyai pengaruh negative dan signifikan terhadap Harga Saham pada perusahaan-perusahaan maufaktur yang terdaftar di Bursa Efek Indonesia.

Hasil uji secara simultan terdapat pengaruh yang signifikan antara variabel bebas yaitu Earning Per Share (EPS), Return On Equity (ROE), Book Value (BV), Pertumbuhan Perusahaan (G) dan Tingkat Kapitalisasi (K) terhadap variabel terikat yaitu Harga Saham pada perusahaanperusahaan manufaktur yang terdaftar di Bursa Efek Indonesia periode 2010-2012. Pengaruh tersebut ditunjukkan pada nilai $F_{\text {hitung }}=188,7111>F_{\text {tabel }}(0.05 ; 5 ; 43)=2,38944$ dengan probabilita 0,00000 lebih kecil dari level signifikan (a) 0,05

Berdasarkan hasil pengujian nilai $\mathrm{R}^{2}=0,956414$, artinya variasi dari perubahan variabel terikat yaitu harga saham (Y) mampu dijelaskan secara serentak oleh variasi variabel bebas yaitu Earning Per Share (X1), Return On Equity (X2), Book Value (X3), Pertumbuhan Perusahaan (X4) dan Tingkat Kapitalisasi (X5) sebesar 95,64\% sedangkan sisanya sebesar 4,36\% dijelaskan oleh faktor lain diluar model seperti inflasi, kurs, valuta asing, politik dan lain-lain.

\section{Pembahasan}

\section{Analisis Pengaruh Earning Per Share (EPS) Terhadap Harga Saham}

Laba per lembar saham (Earning per Share) menunjukkan seberapa besar keuntungan (return) yang diperoleh investor atau pemegang saham per saham. 
Dilihat dari persamaan regressi, diketahui bahwa koefisien pengaruh Earning Per Share (EPS) terhadap harga saham adalah sebesar 0,608645. Artinya jika Earning Per Share naik 1 persen, maka harga saham akan naik sebesar 0,608645 persen, sebaliknya jika Earning Per Share turun 1 persen maka harga saham akan turun sebesar 0,608645 persen.

Berdasarkan uji hipotesis secara parsial (uji t) menunjukkan hasil bahwa Earning Per Share (EPS) berpengaruh positif secara signifikan terhadap harga saham pada perusahaan manufaktur yang terdaftar di Bursa Efek Indonesia periode 2010-2012. Hal ini dijelaskan melalui thitung untuk Earning Per Share (EPS) pada tabel adalah lebih besar dari nilai $t_{\text {tabel }}$ yaitu $8,068593>2,017$ dan begitu juga dengan probabilita yang lebih kecil dari level of significant 0,05 yaitu $0,0000<0,05$. Dengan demikian berarti Earning Per Share (EPS) meningkat maka harga saham juga akan meningkat, hasil penelitian selaras dengan penelitian yang dilakukan oleh Tarigan (2012) menyatakan Earning Per Share (EPS) menunjukkan pengaruh positif terhadap harga saham. Earning Per Share (EPS) dan harga saham memiliki hubungan yang searah sehingga perusahaan sebaiknya meningkatkan Earning Per Share (EPS) untuk meningkatkan harga saham misalnya dengan cara meningkatkan penjualan perusahaan dan meningkatkan efisiensi yang akan diikuti oleh kenaikan earning after tax.

\section{Analisis Pengaruh Return On Equity (ROE) Terhadap Harga Saham}

Return On Equity (ROE) atau tingkat pengembalian ekuitas pemilik mengukur seberapa besar kemampuan perusahaan dalam memperoleh laba yang menjadi hak bagi pemegang saham perusahaan. Dilihat dari persamaan regressi, diketahui bahwa koefisien pengaruh ROE terhadap harga saham adalah sebesar 0,368401. Artinya jika Return On Equity (ROE) naik 1 persen, maka harga saham akan naik sebesar 0,368401 persen, sebaliknya jika Return On Equity (ROE) turun 1 persen maka harga saham akan turun sebesar 0,368401 persen.

Berdasarkan uji hipotesis secara parsial (uji t) menunjukkan bahwa Return On Equity (ROE) berpengaruh positif secara signifikan terhadap harga saham pada perusahaan manufaktur yang terdaftar di Bursa Efek Indonesia periode 2010-2012. Hal ini dijelaskan melalui nilai $t_{\text {hitunguntuk Return }}$ On Equity (ROE) pada tabel adalah lebih besar dari nilai $t_{\text {tabel }}$ yaitu 3,649338 > 2,017 dan begitu juga dengan probabilita yang lebih kecil dari level of significant $(0,05)$ yaitu $0,0000<0,05$. Dengan demikian berarti jika Return On Equity (ROE) meningkat maka harga saham juga akan meningkat, hasil penelitian selaras dengan penelitian yang dilakukan Fitryana (2011) menyatakan Return On Equity (ROE) menunjukkan pengaruh positif terhadap harga saham. Return On Equity (ROE) dan harga saham memiliki hubungan yang searah sehingga perusahaan sebaiknya meningkatkan Return On Equity (ROE) untuk meningkatkan harga saham misalnya dengan cara meningkatkan penjualan perusahaan dan meningkatkan efisiensi yang akan diikuti oleh kenaikan earning after tax.

\section{Pengaruh Book Value (BV) Terhadap Harga Saham}

Nilai Buku (Book Value) digunakan sebagai tolak ukur dalam menentukan wajar atau tidaknya harga saham di pasar (market value). Dilihat dari persamaan regressi, diketahui bahwa koefisien pengaruh Book Value (BV) terhadap harga saham adalah sebesar 0,378354. Artinya jika Book Value (BV) naik 1 persen maka harga saham akan naik sebesar 0,378354 persen, sebaliknya jika Book Value (BV) turun 1 persen maka harga saham akan turun sebesar 0,378354 persen.

Berdasarkan uji hipotesa secara parsial (uji t) menunjukkan bahwa Book Value (BV) berpengaruh positif secara signifikan terhadap harga saham pada perusahaan manufaktur yang terdaftar di Bursa Efek Indonesia periode 2010-2012. Hal ini dijelaskan melalui nilai thitung untuk Book Value (BV) pada tabel adalah lebih besar dari nilai $t_{\text {tabel }}$ yaitu 5,71882 $>2,017$ dan begitu juga dengan probabilita yang lebih kecil dari level of significant $(0,05)$ yaitu $0,0000<0,05$. Dengan demikian berarti jika Book Value (BV) meningkat maka harga saham juga akan meningkat, hasil 
penelitian selaras dengan Fitryana (2011) menyatakan Book Value (BV) menunjukkan pengaruh positif terhadap harga saham. Book Value (BV) dan harga saham memiliki hubungan searah sehingga perusahaan sebaiknya meningkatkan ekuitas perusahaan tersebut. Karena semakin tinggi Book Value (BV) suatu perusahaan berarti nilai riil perusahaan tersebut akan semakin meningkat, berarti akan semakin naik harga sahamnya karena semakin banyak investor yang ingin memiliki saham tersebut.

\section{Pengaruh Pertumbuhan Perusahaan (G) Terhadap Harga Saham}

Pertumbuhan perusahaan diharapkan dapat memberikan aspek yang positif bagi perusahaan. Dari sudut pandang investor, pertumbuhan suatu perusahaan merupakan suatu tand bahwa perusahaan memiliki aspek yang menguntungkan dan mereka mengharapkan rate of return (tingkat pengembalian) dari investasi mereka memberikan hasil yang lebih baik. Dilihat dari persamaan regressi, diketahui bahwa koefisien pengaruh Pertumbuhan Perusahaan (G) terhadap harga saham adalah sebesar 0,182963. Artinya jika Pertumbuhan Perusahaan (G) naik 1 persen maka harga saham akan naik sebesar 0,182963 persen, sebaliknya jika Pertumbuhan Perusahaan $(G)$ turun 1 persen maka harga saham akan turun sebesar 0,182963 persen.

Berdasarkan uji hipotesa secara parsial (uji t) menunjukkan bahwa Pertumbuhan Perusahaan $(G)$ berpengaruh positif namun tidak signifikan terhadap harga saham pada perusahaan manufaktur yang terdaftar di Bursa Efek Indonesia periode 2010-2012. Hal ini dijelaskan melalui nilai thitung untuk Pertumbuhan Perusahaan (G) pada tabel adalah lebih besar dari nilai tabel yaitu 1,900163 < 2,017 dan begitu juga dengan probabilita yang lebih kecil dari level of significant $(0,05)$ yaitu $0,0000<0,05$. Dengan demikian berarti jika Pertumbuhan Perusahaan (G) meningkat harga saham juga akan meningkat, hasil penelitian selaras dengan Sriwardany (2006) yang menyatakan Pertumbuhan Perusahaan (G) menunjukkan pengaruh positif terhadap harga saham. Pertumbuhan Perusahaan $(G)$ dan harga saham memiliki hubungan yang searah sehingga perusahaan sebaiknya meningkatkan penjualan perusahaan sehingga laba per lembar saham meningkat untuk meningkatkan harga saham dan meningkatkan efisiensi yang akan diikuti oleh kenaikan earning after tax.

\section{Pengaruh Tingkat Kapitalisasi (K) Terhadap Harga Saham}

Tingkat kapitalisasi (K) digunakan untuk mengukur tingkat pengembalian yang dituntut oleh pasar terhadap perusahaan. Jika rasio harga laba meningkat, maka tingkat kapitalisasi akan menurun. Dilihat dari persamaan regressi, diketahui bahwa koefisien pengaruh Tingkat Kapitalisasi (K) terhadap harga saham adalah sebesar -0,714897. Artinya jika Tingkat kapitalisasi (K) turun 1 persen maka harga saham akan naik sebesar -0,714897 persen, sebaliknya jika Tingkat Kapitalisasi naik 1 persen maka harga saham akan turun sebesar 0,714897 persen.

Berdasarkan uji hipotesa secara parsial (uji t) menunjukkan bahwa Tingkat Kapitalisasi (K) berpengaruh negatif dan signifikan terhadap harga saham pada perusahaan manufaktur yang terdaftar di Bursa Efek Indonesia periode 2010-2012. Hal ini dijelaskan melalui nilai $t_{\text {hitung }}$ untuk Tingkat Kapitalisasi (K) pada tabel adalah lebih besar dari nilai $\mathrm{t}_{\text {tabel }}$ yaitu $-10,52208<$ 2,017 dan begitu juga dengan probabilita yang lebih kecil dari level of significant $(0,05)$ yaitu $0,0000<0,05$. Dengan demikian berarti jika Tingkat Kapitalisasi $(K)$ meningkat maka harga saham akan menurun, sebaliknya jika Tingkat Kapitalisasi (K) menurun maka harga saham meningkat, hasil penelitian selaras dengan Fitryana (2011) menyatakan Tingkat Kapitalisasi (K) menunjukkan pengaruh negatif terhadap harga saham Tingkat Kapitalisasi (K) dan harga saham memiliki hubungan yang berlawanan arah sehingga perusahaan sebaiknya menurunkan Tingkat Kapitalisasi $(\mathrm{K})$ untuk meningkatkan harga saham. Kapitalisasi yang tinggi dapat 
diturunkan dengan cara mengurangi jumlah nilai nominal modal saham atau mengurangi jumlah lembar saham yang beredar.

Perbedaan Regressi Linear Berganda pada Perusahaan.

Adapun hasil estimasi pengaruh Earning per Share (EPS), Return On Equity (ROE), Book Value (BV), Pertumbuhan Perusahaan (G) dan Tingkat Kapitalisasi (K) terhadap Harga Saham pada perusahaan kecil dan perusahaan besar dapat dilihat pada tabel 3 dan 4 berikut ini:

Tabel 3

Dependent Variable: LOGHARGA_SAHAM

Regressi Linear Berganda Perusahaan Kecil

Method: Least Squares

Date: 06/11/14 Time: 08:43

Sample (adjusted): 338

Included observations: 29 after adjustments

\begin{tabular}{crrrr}
\hline \hline Variable & Coefficient & Std. Error & t-Statistic & Prob. \\
\hline \hline LOGEPS & 0.550483 & 0.105997 & 5.193389 & 0.0000 \\
LOGROE & 0.242900 & 0.129864 & 1.870419 & 0.0742 \\
LOGBV & 0.599660 & 0.107450 & 5.580847 & 0.0000 \\
LOGG & 0.446255 & 0.147110 & 3.033477 & 0.0059 \\
LOGK & -0.591115 & 0.092786 & -6.370771 & 0.0000 \\
C & -0.413245 & 0.944293 & -0.437624 & 0.6657 \\
\hline \hline R-squared & 0.961772 & Mean dependent var & 7.461784 \\
Adjusted R-squared & 0.953462 & S.D. dependent var & 1.957104 \\
F-statistic & 115.7308 & Durbin-Watson stat & 2.506377 \\
Prob(F-statistic) & 0.000000 & & & \\
\hline \hline
\end{tabular}

Sumber: Lampiran 3 diolah menggunakan Eviews 7

Berdasarkan hasil pengkajian dengan metode linear berganda perusahaan kecil, maka dapat disusun persamaan sebagai berikut:

$Y=0,550483 X 1+0,242900 X 2+0,599660 X 3+0,446255 X 4-0,591115 X 5-0,413245$

Tabel 4

Regressi Linear Berganda Perusahaan Besar

Dependent Variable: LOGHARGA_SAHAM

Method: Least Squares

Date: 06/11/14 Time: 08:25

Sample: 121

Included observations: 20

\begin{tabular}{crrrr}
\hline \hline Variable & Coefficient & Std. Error & t-Statistic & Prob. \\
\hline \hline LOGEPS & 0.817828 & 0.087445 & 9.352472 & 0.0000 \\
LOGROE & 0.193770 & 0.107332 & 1.805322 & 0.0926 \\
LOGBV & 0.094511 & 0.082966 & 1.139155 & 0.2738 \\
LOGG & -0.004155 & 0.069132 & -0.060106 & 0.9529 \\
LOGK & -0.882371 & 0.052836 & -16.70014 & 0.0000 \\
C & 4.144281 & 0.503297 & 8.234271 & 0.0000
\end{tabular}




\begin{tabular}{llll}
\hline \hline R-squared & 0.992234 & Mean dependent var & 8.080731 \\
Adjusted R-squared & 0.989461 & S.D. dependent var & 1.147203 \\
F-statistic & 357.7565 & Durbin-Watson stat & 2.045470 \\
Prob(F-statistic) & 0.000000 & & \\
\hline \hline
\end{tabular}

Sumber: Lampiran 4 diolah menggunakan Eviews 7

Berdasarkan hasil pengkajian dengan metode linear berganda perusahaan besar, maka dapat disusun persamaan sebagai berikut:

$\mathrm{Y}=0,817828 \mathrm{X} 1+0,193770 \mathrm{X} 2+0,094511 X 3-0,004155 X 4-0,882371 X 5-4,144281$

Ciri-ciri perusahaan kecil adalah: (a) umunya dikelola pemilik, (b) Struktur organisasi sederhana, (c) Pemilik mengenal karyawan, (d) Prosentase kegagalan perusahaan tinggi, (e) Kekurangan manajer yang ahli, (f) Modal jangka panjang sulit diperoleh. Ciri-ciri perusahaan besar adalah: (a) dikelola bukan oleh pemilik, (b) struktur organisasi kompleks, (c) pemilik mengenal sedikit karyawan, (d) prosentase kegagalan rendah, (e) banyak ahli manajemen, (f) modal jangka panjang relative mudah diperoleh (Rasyid, 2014)

Berdasarkan kedua tabel regressi linear berganda dari perusahaan kecil dan perusahaan besar, dapat dilihat perbandingan antara koefisien perusahaan kecil dengan perusahaan besar. Dari hasil penelitian tersebut, diketahui bahwa dari kelima variabel yang diteliti, ada 4 variabel koefisien regressi perusahaan kecil yang lebih besar dibandingkan dengan koefisien regressi perusahaan besar, hal ini dapat dilihat dari nilai coefficient dari masing-masing variabel. Earning Per Share (EPS) pada perusahaan besar sebesar 0,817828 dibandingkan dengan Earning Per Share (EPS) pada perusahaan kecil sebesar 0,550483. Dalam hal ini berarti Earning Per Share (EPS) pada perusahaan besar lebih besar mempengaruhi harga saham daripada perusahaan kecil yang mengakibatkan harga saham perusahaan bisa meningkat karena Earning Per Share (EPS) memiliki pengaruh yang positif terhadap harga saham. Return On Equity (ROE) pada perusahaan besar sebesar 0,193770 dibandingkan dengan Return On Equity (ROE) pada perusahaan kecil sebesar 0,242900. Dalam hal ini berarti Return On Equity (ROE) pada perusahaan kecil lebih besar mempengaruhi harga saham dibandingkan dengan perusahaan besar yang mengakibatkan harga saham perusahaan bisa meningkat karena Return On Equity (ROE) memiliki pengaruh yang positif terhadap harga saham. Book Value (BV) pada perusahaan besar sebesar 0,094511 dibandingkan dengan Book Value (BV) pada perusahaan kecil sebesar 0,599660. Dalam hal ini berarti Book Value (BV) pada perusahaan kecil lebih besar mempengaruhi harga saham dibandingkan dengan perusahaan besar yang mengakibatkan harga saham perusahaan bisa meningkat karena Book Value (BV) memiliki pengaruh yang positif terhadap harga saham. Pertumbuhan Perusahaan (G) pada perusahaan besar sebesar -0,004155 dibandingkan dengan Pertumbuhan perusahaan $(G)$ pada perusahaan kecil sebesar 0,446255. Dalam hal ini berarti Pertumbuhan perusahaan $(G)$ pada perusahaan kecil lebih besar mempengaruhi harga saham dibandingkan dengan perusahaan besar yang mengakibatkan harga saham perusahaan bisa meningkat karena Pertumbuhan Perusahaan (G) memiliki pengaruh yang positif terhadap harga saham. Tingkat kapitalisasi (K) pada perusahaan besar sebesar 0,882371 dibandingkan dengan perusahaan kecil pada tingkat kapitalisasi (K) sebesar 0,591115. Dalam hal ini berarti tingkat kapitalisasi (K) pada perusahaan besar lebih besar mempengaruhi harga saham yang mengakibatkan harga saham pada perusahaan besar menurun, karena tingkat kapitalisasi (K) memiliki pengaruh yang negatif terhadap harga saham. Dari perbedaan kedua regressi linear berganda antara perusahaan kecil dan perusahaan besar maka dapat disimpulkan jika investor yang ingin mendapatkan atau 
memperoleh capital gain atau merupakan selisih antara harga jual dan harga beli maka investor lebih baik berinvestasi di perusahaan kecil karena prediksi harga saham lebih besar dipengaruhi oleh koefisien regressi, Return On Equity (ROE), Book Value (BV), Pertumbuhan perusahaan $(G)$ pada perusahaan kecil daripada perusahaan besar. Untuk Investor yang mengharapkan dividen atau hasil/imbalan yang diperoleh para pemegang saham sebaiknya berinvestasi di perusahaan besar. Hal ini karena koefisien Earning Per Share (EPS) pada perusahaan besar lebih besar dari pada koefisien Earning Per Share (EPS) pada perusahaan kecil yang mempengaruhi harga saham, yang berari tingkat Earning Per Share (EPS) atau laba per lembar saham lebih besar di perusahaan besar dari pada di perusahaan kecil. Sebab Earning Per Share (EPS) merupakan tingkat keuntungan bersih yang mampu diraih perusahaan pada saat menjalankan operasinya. Dividen akan dibagikan apabila perusahaan memperoleh keuntungan.

Dari hasil regressi linear berganda perusahaan kecil dan perusahaan besar dapat dilihat bahwa Pertumbuhan perusahaan $(G)$ pada perusahaan kecil lebih besar mempengaruhi harga saham dibandingkan dengan perusahaan besar. Pada perusahaan besar Pertumbuhan perusahaan $(\mathrm{G})$ tidak mempengaruhi harga saham karena perusahaan itu termasuk perusahaan yang sudah mapan dan pertumbuhannya sudah maksimal sehingga tidak diperlukan lagi untuk meningkatkan pertumbuhan perusahaannya sehingga harga saham pada perusahaan besar tetap. Namun pada perusahaan kecil, karena adanya pengaruh pertumbuhan perusahaan (G) terhadap perusahaan maka harga saham akan naik sehingga diharapkan investor untuk membeli saham pada perusahaan kecil karena dengan naiknya harga saham pada perusahaan kecil maka investor akan memperoleh dividen yang lebih besar.

Berdasarkan ciri-ciri perusahaan diketahui bahwa pada umumnya tingkat resiko pada perusahaan kecil lebih besar dibandingkan dengan tingkat resiko pada perusahaan besar. Hal itu dapat dilihat dari tingkat kapitalisasi (K) perusahaan. Namun pada kenyataannya dari hasil penelitian pada regressi linear berganda perusahaan kecil dan perusahaan besar diatas bahwa tingkat kapitalisasi $(\mathrm{K})$ pada pada perusahaan besar lebih besar dibandingkan dengan tingkat kapitalisasi (K) pada perusahaan kecil. Hal inilah yang menyebabkan perusahaan besar lebih banyak mengalami kebangkrutan dibandingkan dengan perusahaan kecil. Maka hal yang perlu dilakukan untuk mengurangi tingkat kapitalisasi $(\mathrm{K})$ adalah dengan cara mengurangi jumlah nominal modal saham atau mengurangi jumlah lembar saham yang beredar.

R-squared untuk perusahaan kecil yaitu sebesar 0,961772, menandakan bahwa variasi dari perubahan dari variabel terikat yaitu harga saham $(\mathrm{Y})$ mampu dijelaskan secara serentak oleh variasi variabel bebas yaitu Earning Per Share (X1), Return On Equity (X2), Book Value (X3), Pertumbuhan perusahaan (X4) dan tingkat kapitalisasi (X5) sebesar 96,18 persen, sedangkan sisanya sebesar 3,82 persen dijelaskan oleh faktor lain di luar model.

R-squared untuk perusahaan besar yaitu sebesar 0,992234 menandakan bahwa variasi dari perubahan dari variasi variabel terikat yaitu harga saham (Y) mampu dijelaskan secara serentak oleh variasi variabel bebas yaitu Earning Per Share (X1), Return On Equity (X2), Book Value (X3), Pertumbuhan perusahaan (X4) dan tingkat kapitalisasi (X5) sebesar 99,22\%, sedangkan sisanya sebesar $0,78 \%$ dijelaskan oleh faktor lain di luar model.

Dari kedua hasil regressi tersebut, R-squared antara perusahaan besar dan perusahaan kecil maka dapat disimpulkan bahwa Earning Per Share (X1), Return On Equity (X2), Book Value (X3), Pertumbuhan perusahaan (X4) dan tingkat kapitalisasi (X5) pada perusahaan besar lebih mempengaruhi dan lebih dapat menjelaskan perubahan harga saham dari pada perusahaan kecil, karena perusahaan besar memiliki R-squared yang lebih besar dibandingkan dengan Rsquared pada perusahaan kecil. Selain itu, karakteristik perusahaan juga mempengaruhi harga 
saham yaitu dapat dilihat dari R-squared perusahaan besar lebih besar dari pada R-squared perusahaan kecil.

\section{Kesimpulan}

\section{SIMPULAN DAN SARAN}

Berdasarkan penelitian ini dapat diambil kesimpulan sebagai berikut:

1. Secara simultan terdapat pengaruh yang signifikan antara Earning Per Share (EPS), Return On Equity (ROE), Book Value (BV) dan tingkat kapitalisasi (K) dan juga pengaruh yang tidak signifikan antara Pertumbuhan perusahaan $(G)$ terhadap harga saham pada perusahaanperusahaan manufaktur baik perusahaan secara umum maupun perusahaan kecil dan perusahaan besar yang terdaftar di Bursa efek Indonesia periode 2010-2012 dengan level of significant sebesar 0,05.

2. Secara parsial diketahui bahwa Earning Per Share (EPS), Return On Equity (ROE), Book Value (BV) dan Pertumbuhan perusahaan $(\mathrm{G})$ memiliki pengaruh yang positif terhadap harga saham pada perusahaan-perusahaan manufaktur yang terdaftar di Bursa Efek Indonesia periode 2010-2012 dengan level of significant sebesar 0,05 sehingga peningkatan persentase Earning Per Share (EPS), Rerturn On Equity (ROE), Book Value (BV) dan Pertumbuhan perusahaan $(\mathrm{G})$ cenderung meningkatkan harga saham.

3. Secara parsial bahwa tingkat kapitalisasi $(\mathrm{K})$ memiliki pengaruh yang negatif terhadap harga saham pada perusahaan-perusahaan manufaktur yang terdaftar di Bursa Efek Indonesia periode 2010-2012 dengan level of significant sebesar 0,05 sehingga peningkatan persentase tingkat kapitalisasi cenderung menurunkan harga saham.

4. Harga saham pada perusahaan secara umum dapat dijelaskan oleh Earning Per Share (EPS), Return On Equity (ROE), Book Value (BV), pertumbuhan perusahaan (G) dan tingkat kapitalisasi (K) sebesar 95,64\% sedangkan 4,36\% lagi dijelaskan oleh faktor lain diluar penelitian. Harga saham pada perusahaan kecil dapat dijelaskan oleh Earning Per Share (EPS), Return On Equity (ROE), Book Value (BV), pertumbuhan perusahaan (G) dan tingkat kapitalisasi (K) sebesar 96,18\% sedangkan 3,82\% lagi dijelaskan oleh faktor lain diluar penelitian. Harga saham pada perusahaan besar dapat dijelaskan oleh Earning Per Share (EPS), Return On Equity (ROE), Book Value (BV), pertumbuhan perusahaan (G) dan tingkat kapitalisasi (K) sebesar 99,22\% sedangkan 0,78\% lagi dijelaskan oleh faktor lain diluar penelitian. Faktor lain diluar model tersebut misalnya inflasi, kurs valuta asing, politik dan dapat juga dipengaruhi oleh karakteristik perusahaan.

\section{Saran}

1. Berdasarkan hasil penelitian, menunjukkan bahwa Earning Per Share, Return On Equity (ROE), Book Value (BV) dan Pertumbuhan perusahaan (G) berpengaruh positif terhadap harga saham perusahaan-perusahaan manufaktur yang terdaftar di Bursa Efek Indonesia. Dari hasil tersebut, sebaiknya pihak perusahaan mampu menaikkan rasio Earning Per Share (EPS), Return On Equity (ROE), Book Value (BV) dan Pertumbuhan perusahaan (G), misalnya dengan meningkatkan net sales sehingga harga saham dapat meningkat. Pihak perusahaan sebaiknya menurunkan tingkat kapitalisasi (K) karena jika tingkat kapitalisasi (K) meningkat maka harga saham akan turun. Menurunkan tingkat kapitalisasi (K) dapat dilakukan dengan cara mengurangi jumlah nominal modal saham atau mengurangi jumlah lembar saham yang beredar.

2. Bagi investor yang mengharapkan dividen maka sebaiknya berinvestasi di perusahaan besar karena perusahaan besar memiliki koefisien regresi Earning Per Share (EPS) yang 
lebih besar daripada perusahaan kecil artinya Earning Per Share (EPS) lebih mempengaruhi harga saham di perusahaan besar daripada di perusahaan kecil.

3. Bagi investor yang ingin mendapatkan atau memperoleh capital gain atau merupakan selisih antara harga jual dan harga beli maka investor lebih baik berinvestasi di perusahaan kecil karena prediksi harga saham lebih besar dipengaruhi oleh koefisien regressi Return On Equity (ROE), Book Value (BV), Pertumbuhan Perusahaan (G) dan Tingkat kapitalisasi (K) pada perusahaan kecil daripada perusahaan besar.

4. Kepada peneliti selanjutnya yang berminat meneliti dengan penelitian yang sama, disarankan agar menambah variabel penelitian agar memperluas permasalahan yang akan dibahas.

\section{DAFTAR PUSTAKA}

A.F.Stoner james,dkk. 1996. Manajemen. Edisi Bahasa Indonesia. Penerbit: PT. Prenhallindo. Jakarta.

Brigham, Eugene F \& Houston, Joel F. 2001. Manajemen Keuangan, Edisi ke Delapan, Penerbit : BPFE. Yogyakarta.

Budianas, N. (2013). Pengertian Harga Saham (Online). Tersedia: http://www.nanangbudianas.blogspot.com/2013/02/pengertian-harga-saham.html (diakses 20 Maret 2014)

Cahyaningrum, Ndaru Hesti. 2012. Analisis Manfaat Rasio Keuangan Dalam Memprediksi Pertumbuhan Laba. Skripsi Universitas Diponegoro. Jurnal Online.

Fahmi, Irham. 2012. Manajemen Investasi Teori dan Soal Jawab. Jakarta: Penerbit Salemba Empat.

FinanceRoll. Harga Saham: Tempat Membeli Saham. Informasi Harga Saham, http://www.financeroll.co.id/uncategorized/harga-saham/ (diakses 21 Maret 2014)

Fitriana, Agnes. 2011. Analisis Pengaruh Faktor Fundamental dan Pasar Terhadap Harga Saham pada Perusahaan Sektor Property dan Real Estate yang Listing di Bursa Efek Indonesia. Skripsi. Medan: Program Sarjana Universitas Katolik Santo Thomas Sumatera Utara.

Gitman, Lawrence J. 2003. Principles of Manajerial Finance. Edisi Kesepuluh.

Hadiningsih, Sri dkk. 1998. Perangkat Analisis dan Teknik Analisis Investasi di Pasar Modal Indonesia. Jakarta: PT. Bursa Efek Indonesia.

Jogiyanto Hartono. 2010. Teori Portofolio \& Analisis Investasi. Yogyakarta: BPFE.

Manurung, Jonni. 2010. Ekonometrika: Teknik Pemodelan Dasar dan Lanjutan. Medan.

Nainggolan, Susan. 2008. Pengaruh Variabel Fundamental Terhadap Harga Saham Perusahaan Manufaktur yang Terdaftar di Bursa Efek Indonesia. Tesis. Medan: Program Pascasarjana Universitas Sumatera Utara.

Rasyid, al. (2014). Entrepreneur-Kewirausahaan. (Online). Tersedia: http://alrasyid.blog.undip.ac.id/tag/perusahaan-besar (diakses 10 Juni 2014). 
Setianingsih, Dewi D. 2006. Analisis Pengaruh Faktor Fundamental dan Risiko Pasar Terhadap Harga Pasar Perusahaan Manufaktur di Bursa Efek Jakarta Pada Waktu Ex-Dividen Day. Skripsi. Program Sarjana Universitas Indonusa Esa Unggul.

Sugiono. 2004. Metode Penelitian Bisnis. CV. Alfabeta: Bandung.

Tandelilin, Eduardus. 2001. Portofolio E Investasi Teori dan Aplikasi. Yogyakarta: Kanisius.

Tarigan, Elsania. 2012. Beberapa Faktor Fundamental Terhadap Harga Saham Pada Perusahaan Manufaktur di Bursa Efek Indonesia (BEI). Skripsi. Medan: Program Sarjana Universitas Katolik Santo Thomas Sumatera Utara.

Tryfino. 2009. Cara Cerdas Berinvestasi Saham. Jakarta: Transmedia Pustaka.

Weston, J. Fred dan Brigham, Eugene F. 2001. Dasar-Dasar Manajemen Keuangan. Jakarta: Penerbit Erlangga.

$\underline{\text { www.idx.co.id }}$

www.sahamok.com 